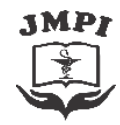

Jurnal Mandala Pharmacon Indonesia, Vol 7.No.1 Juni 2021

Avaiable online at www.jurnal-pharmaconmw.com/jmpi

p-ISSN : 2442-6032

$e$-ISSN : 2598-9979

\title{
Evaluasi Rasionalitas Penggunaan Obat Anti Inflamasi Non Steroid (OAINS) Di Puskesmas Poli-Polia Kabupaten Kolaka Timur
}

\author{
Bai Athur Ridwan ${ }^{1 *}$, Yulli Fety ${ }^{2}$, Nurlinda $^{1}$ \\ ${ }^{1}$ Prodi Farmasi, Universitas Mandala Waluya, ${ }^{2}$ Prodi Profesi Ners, Universitas Mandala Waluya
}

\begin{abstract}
ABSTRAK
Nyeri didefinisikan sebagai perasaan tidak menyenangkan oleh sebagian orang akibat dari kerusakan jaringan, sehingga pasien melakukan pengobatan dan penggunaan Obat Anti Inflamasi Non Steroid (OAINS) masih menjadi pilihan utama sebagai terapi farmakologi. Adanya efek samping yang bisa terjadi maka perlu ditunjang dengan penggunaan yang rasional khususnya pada fasilitas kesehatan. penelitian ini bertujuan untuk mengetahui gambaran rasionalitas penggunaan OAINS di Puskesmas Poli-Polia Kabupaten Kolaka Timur. Jenis penelitian ini merupakan penelitian non eksperimental dengan desain deskriptif retrospektif. Sampel diambil dengan cara total sampling dari populasi yang memenuhi kriteria inklusi yaitu OAINS tunggal maupun kombinasi yang digunakan pasien periode Januari - Maret 2020 dan memiliki data rekam medik lengkap. Jumlah sampel yang diperoleh yaitu sebesar 72
\end{abstract}

pasien. Data dikumpulkan dalam lembar pengumpul data yang memuat identitas pasien, nama obat, dosis, dan aturan pakai. Analisis rasionalitas penggunaan OAINS dinilai dari aspek ketepatan pemilihan obat, ketepatan jumlah dan ketepatan dosis serta frekuensi yang disajikan secara deskriptif. Hasil penelitian menunjukkan bahwa penggunaan OAINS di Puskesmas PoliPolia Kabupaten Kolaka Timur belum sepenuhnya memenuhi rasionalitas penggunaan obat. Aspek tepat pemilihan obat diperoleh sebesar 86\%, tepat dosis dan frekuensi pemberian sebesar $83 \%$, dan tepat jumlah obat mencapai $100 \%$, sehingga penggunaan OAINS di Puskesmas Poli-Polia Kabupaten Kolaka Timur belum rasional.

Kata Kunci : Rasionalitas, Obat Anti Inflamasi Non Steroid, OAINS, Puskesmas

\section{ABSTRACT}

Pain is defined as an unpleasant feeling for some people as a result of tissue damage, so patients do treatment and most are still centered on pharmacological therapies such as the use of NonSteroidal Anti-Inflammatory Drugs (NSAIDs). There are side effects that can occur, it needs to be supported by rational use, especially in health facilities. This study aims to find out the rationality of the use of NSAIDs in the Puskesmas Poli-Polia East Kolaka Regency. This type of research is nonexperimental research with a retrospective descriptive design. Samples were taken by a total sampling of the population that meets the inclusion criteria, namely single and combination NSAIDs used by patients in the period January - March 2020, and have complete medical record data. The number of samples obtained in 72 patients and the data is collected in a data collection sheet containing the patient's identity, drug name, dosage, and usage rules. Rationality analysis of the use of NSAIDs is assessed from the aspect of the accuracy of drug selection, determination of quantity, and accuracy of doses and frequencies presented descriptively. The results showed that the rationality of the use of NSAIDs in the Puskesmas Poli-Polia East Kolaka Regency is not entirely appropriate. In the right aspect of drug selection obtained by $86 \%$, the exact dose and frequency of administration by $83 \%$, and the right amount of medicine reached $100 \%$ and in a sense that the NSAIDs used in the Puskesmas Poli-Polia East Kolaka Regency have not been rational.

Keywords : Rationality, Non-Steroidal AntiInflammatory Drugs, NSAIDs, Puskesmas
Penulis Korespondensi :

Bai Athur Ridwan

Prodi Farmasi, Universitas Mandala Waluya

E-mail : baiathurridwano5@gmail.com
Informasi Artikel

Submitted

Accepted

Published
: 7 Mei 2021

: 25 Mei 2021

: 30 Juni 2021 


\section{PENDAHULUAN}

Nyeri didefinisikan sebagai perasaan tidak menyenangkan bagi sebagian orang akibat dari kerusakan jaringan. Nyeri juga dapat menjadi peringatan adanya ancaman terhadap tubuh yang bersifat aktual maupun potensial (Andarmoyo, 2013; Bahrudin, 2018). Oleh karena itu nyeri tidak dapat dianggap remeh karena memiliki dampak cukup besar pada kondisi biologis, psikologis, sosiologis, dan ekonomi pasien. Hal ini menyebabkan pasien akan mencari pengobatan dari berbagai pilihan penatalaksanaan klinis yang tersedia dan kebanyakan masih berpusat pada terapi farmakologis salah satunya yaitu dengan penggunaan Obat Anti Inflamasi NonSteroid (OAINS) (Schug \& Goddard, 2014).

OAINS merupakan kategori obat yang memiliki mekanisme kerja dan aktivitas terapeutik yang sama sebagai anti piretik, analgesik, dan anti inflamasi (Sostres \& Lanas, 2016). OAINS digunakan untuk pengobatan nyeri otot, dismenore, rematik, asam urat, migrain dan trauma akut tertentu. Mekanisme kerja utama dari OAINS adalah menghambat enzim siklooksigenase (COX). COX ini diperlukan untuk mengubah asam arakidonat menjadi tromboksan, prostaglandin, dan prostasiklin. Isoensim siklooksigenase ini terdiri dari $\operatorname{COX} 1$ dan $\operatorname{COX} 2 . \operatorname{COX} 1$ diekspresikan secara konstitusif dalam tubuh yang berperan dalam melindungi lapisan mukosa saluran cerna, fungsi ginjal, dan agregasi trombosit, sedangkan COX 2 diekspresikan secara induktif selama respon inflamasi atau hanya menargetkan COX 2. Namun sebagian besar OAINS tidak selektif dan menghambat kedua siklooksigenase tersebut (Ghlichloo \& Gerriets, 2021). Hal ini menyebabkan OAINS memiliki berbagai efek samping seperti kerusakan mukosa pada saluran gastrointestinal, obstruksi, disfungsi ginjal, kejadian kardiovaskuler (peningkatan resiko hipertensi, strok, serangan jantung), bahkan sampai kematian (Meara \& Simon, 2013). Berdasarkan hal tersebut maka rasionalitas penggunaan OAINS perlu ditegakkan dengan baik untuk menghindari terjadinya efek samping ataupun dampak negatif lainnya yang merugikan pasien.

Penggunaan obat dikatakan rasional jika pasien menerima obat sesuai dengan kebutuhan klinisnya, dosis yang sesuai, dalam jangka waktu yang adequate, dan biaya yang terjangkau (WHO, 2021). Secara praktis, penggunaan obat rasional jika memenuhi kriteria tepat diagnosis, tepat indikasi penyakit, tepat pemilihan obat, tepat dosis, tepat cara pemberian, tepat interval waktu pemberian, tepat lama pemberian, waspada terhadap efek samping, tepat penilaian kondisi pasien, obat yang diberikan harus efektif dan aman serta 
harga terjangkau, tepat informasi, tepat tindak lanjut, tepat penyerahan obat, dan pasien patuh terhadap perintah pengobatan yang dibutuhkan (Kemenkes RI, 2011). Penggunaan obat secara rasional dapat meningkatkan derajat kesehatan atau menguntungkan dari segi ekonomi masyarakat sehingga mendukung produktivitas kerja dan ketahanan nasional (Ihsan et al., 2017). Namun hal ini masih menjadi tantangan dan masalah besar karena masih terdapat penggunaan obat yang tidak rasional.

Beberapa penelitian menunjukkan bahwa masih terdapat ketidak rasionalan dalam penggunaan obat. Berdasarkan penelitian (Wahyuni, Diana, \& Suprianto, 2019) menunjukkan bahwa penggunaan OAINS pada Puskesmas A di Kabupaten Gayo Lues Aceh masih belum rasional ditinjau dari ketepatan indikasi resep yaitu sebesar 80\% dan ketepatan penggunaan obat sebesar 94,29\% dari standar 100\%. Dalam penelitian lain seperti yang dilaporkan oleh (Ihsan et al., 2017) menunjukkan bahwa rasionalitas penggunaan obat pada seluruh Puskesmas Kota Kendari Tahun 2016 menurut indikator peresepan WHO belum rasional kecuali pada parameter persentase peresepan injeksi. Ketidak rasionalan penggunaan obat tersebut dapat memicu munculnya masalah kesehatan baru. Oleh karena itu pemerintah melakukan berbagai intervensi, salah satunya melalui program POR (Penggunaan Obat
Rasional) pada tingkat pelayanan kesehatan termasuk Puskesmas yang merupakan rujukan pertama bagi masyarakat untuk mendapatkan pelayanan kesehatan dasar. Keberhasilan POR ini juga di dukung oleh kualitas dan kuantitas tenaga farmasi (Kemenkes RI, 2011).

Puskesmas Poli-Polia merupakan Puskesmas Kecamatan yang terdapat di Kabupaten Kolaka Timur. Dari sisi sumber daya manusia, Puskesmas ini belum memiliki apoteker. Oleh karena itu maka perlu dilakukan penelitian tentang evaluasi rasionalitas penggunaan Obat Anti Inflamasi Non Sterodi (OAINS) di Puskesmas Poli-Polia Kabupaten Kolaka Timur. Tujuan penelitian ini yaitu untuk mengetahui gambaran rasionalitas penggunaan Obat Anti Inflmasi Non Steroid (OAINS) di Puskesmas Poli-Polia Kabupaten Kolaka Timur.

\section{METODE PENELITIAN}

\section{A.Jenis dan Desain Penelitian}

Jenis penelitian ini merupakan penelitian non eksperimental dengan desain deskriptif retrospektif menggunakan data rekam medik pasien yang menggunakan OAINS pada periode Januari - Maret 2020.

\section{B.Lokasi dan Waktu Penelitian}

Penelitian ini dilaksanakan di Puskesmas Polia-Polia Kabupaten Kolaka Timur pada bulan Agustus - September 2020. 


\section{C.Populasi dan Sampel}

Populasi pada penelitian ini yaitu seluruh data rekam medik pasien di Puskesmas Poli-Polia Kabupaten Kolaka Timur yang mendapat Obat Anti Inflamasi Non Steroid (OAINS) periode Januari Maret 2020. Sampel pada penelitian ini yaitu populasi yang memenuhi kriteria inklusi penelitian yaitu pasien yang menggunakan OAINS tunggal maupun kombinasi pada periode Januari - Maret 2020 dan memiliki data rekam medik yang lengkap berupa identitas pasien, tanggal pemeriksaan, diagnosis dan terapi, sedangkan kriteria eksklusinya yaitu data rekam medik pasien tidak lengkap dan tulisan tidak jelas terbaca atau terpotong. Adapun sampel yang diperoleh yaitu berjumlah 72 sampel sehingga pengambilan sampel dilakukan dengan cara total sampling.

\section{D.Pengolahan dan Analisis Data}

Data dikumpulkan dalam lembar pengumpul data yang memuat identitas pasien, nama obat, dosis, dan aturan pakai. Analisis rasionalitas penggunaan OAINS dari aspek ketepatan pemilihan obat, ketepatan jumlah obat dan ketepatan dosis dan frekuensi ditentukan menggunakan literatur Applied Therapeutics: The Clinical Use of Drugs $10^{\text {th }}$ Edition, Lippincott's Ilustrated Reviews: Pharmacology $4^{\text {th }}$ Edition, dan AHFS Drug Information Essentials serta dinilai berdasarkan perhitungan berikut: a. \% Ketepatan pemilihan obat = $\frac{\text { Jumlah kasus tepat pemilihan obat }}{\text { Total kasus }} \times 100 \%$

b. \% Ketepatan jumlah obat = $\frac{\text { Jumlah kasus tepat jumlah obat }}{\text { Total kasus }} \times 100 \%$

c. \% Ketepatan dosis dan frekuensi = $\frac{\text { Jumlah kasus tepat dosis dan frekuensi }}{\text { Total kasus }} \times 100 \%$

\section{HASIL DAN PEMBAHASAN}

\section{Karakteristik Pasien}

Berdasarkan data penelitian, pasien yang menggunakan OAINS yaitu sebanyak 72 pasien yang terdiri dari 30 laki-laki (42\%) dan 42 perempuan (58\%). Adapun karakteristik usia pasien pada periode Januari - Maret 2020 dibagi dalam 4 kelompok umur yaitu 12 - 25 tahun (remaja), 26 - 45 tahun (dewasa), $46-65$ tahun (lansia), dan > 65 tahun (manula) dengan persentase paling banyak yang memperoleh OAINS adalah kelompok umur manula sebesar $44 \%$ dan paling sedikit pada kelompok usia remaja sebesar $3 \%$, sebagaimana terdapat pada tabel 1.

\section{Penggunaan OAINS yang} didominasi oleh pasien perempuan sejalan dengan penelitian (Waranugraha et al., 2013) yang menyatakan bahwa banyak perempuan yang menggunakan OAINS karena lebih sering mengalami penyakit rematik dibanding dengan pria. Selain itu, menurut (Soleha et al., 2018) menyatakan bahwa prevalensi dari 
penyakit sendi meningkat seiring dengan bertambahnya usia. Pemberian OAINS cukup menjadi tantangan bagi tenaga kesehatan jika diberikan pada pasien yang berusia lanjut.

Tabel 1. Distribusi pasien berdasarkan jenis kelamin dan usia

\begin{tabular}{|c|c|c|c|c|}
\hline No & $\begin{array}{l}\text { Karakt } \\
\text { Pasien }\end{array}$ & stik & Jumlah & $\begin{array}{c}\text { Persent } \\
\text { ase }\end{array}$ \\
\hline \multirow{2}{*}{1} & \multirow{2}{*}{$\begin{array}{l}\text { Jenis } \\
\text { Kelamin }\end{array}$} & $\begin{array}{l}\text { Laki- } \\
\text { Laki }\end{array}$ & 30 & $42 \%$ \\
\hline & & $\begin{array}{l}\text { Peremp } \\
\text { uan }\end{array}$ & 42 & $58 \%$ \\
\hline \multirow{4}{*}{2} & \multirow{4}{*}{ Usia } & $12-25$ & 2 & $3 \%$ \\
\hline & & $26-45$ & 20 & $28 \%$ \\
\hline & & $46-65$ & 18 & $25 \%$ \\
\hline & & $>65$ & 32 & $44 \%$ \\
\hline
\end{tabular}

Penatalaksanaan nyeri pada lansia maupun manula menjadi tantangan cukup signifikan karena secara fisiologis fungsi dari organ tubuh lansia terlebih pada manula telah mengalami perubahan sehingga penting untuk dipertimbangkan pengobatan farmakologis yang tepat, salah satunya penggunaan terapi OAINS. Maka yang perlu diketahui bahwa pada lansia maupun manula terdapat peningkatan sensitivitas terhadap kerja obat sehingga penggunaan OAINS perlu dimulai dari dosis rendah kemudian dinaikkan secara bertahap sesuai dengan sasaran pengobatan karena OAINS dapat memperburuk derajat gagal ginjal sehingga tidak dianjurkan penggunaannya pada pasien dengan gagal ginjal (Barus, 2015). Selain itu, (Waranugraha et al., 2013) juga menyatakan bahwa proses penuaan menyebabkan efek samping obat lebih dominan dan efek toksis akan lebih sering muncul daripada efek terapeutiknya.

\section{Rasionalitas penggunaan obat}

Pada penelitian ini ditemukan bahwa OAINS yang digunakan oleh pasien yaitu paracetamol, ibuprofen, natrium diklofenak, asam mefenamat dan meloxicam. OAINS yang banyak digunakan adalah meloxicam. Menurut (Waranugraha et al., 2013) menyatakan bahwa penggunaan meloxicam dinilai paling aman karena memiliki efek samping minimal terhadap terjadinya gastropati bagi pasien terapi jangka panjang akibat penyakit kronis yang dialaminya. Dalam penelitian ini, evaluasi rasionalitas penggunaan obat dinilai berdasarkan aspek ketepatan pemilihan obat, ketepatan jumlah dan ketepatan dosis serta frekuensi pemberian OAINS disesuaikan dengan literatur Applied Therapeutics: The Clinical Use of Drugs $10^{\text {th }}$ Edition, Lippincott's Ilustrated Reviews: Pharmacology $4^{\text {th }}$ Edition, dan AHFS Drug Information Essentials. Penggunaan obat dapat dikatakan rasional jika memenuhi seluruh aspek ketepatan tersebut. Hasil kajian dari data sampel yang diperoleh di Puskesmas Poli-Polia Kabuaten Kolaka Timur dapat dilihat pada tabel 2 berikut. 
Tabel 2. Rasionalitas Penggunaan OAINS di Puskesmas Poli-Polia Kabupaten Kolaka Timur Periode Januri Maret 2020

\begin{tabular}{|c|c|c|c|}
\hline No & $\begin{array}{c}\text { Parameter } \\
\text { Rasionalitas } \\
\text { OAINS }\end{array}$ & Jumlah & Persentase \\
\hline 1 & $\begin{array}{l}\text { Tepat Pemilihan } \\
\text { Obat }\end{array}$ & & \\
\hline & Tepat & 62 & $86 \%$ \\
\hline & Tidak Tepat & 10 & $14 \%$ \\
\hline 2 & Tepat Jumlah & & \\
\hline & Tepat & 72 & $100 \%$ \\
\hline & Tidak tepat & O & $0 \%$ \\
\hline 3 & $\begin{array}{l}\text { Tepat Dosis dan } \\
\text { Frekuensi } \\
\text { Pemberian }\end{array}$ & & \\
\hline & Tepat & 60 & $83 \%$ \\
\hline & Tidak Tepat & 12 & $17 \%$ \\
\hline
\end{tabular}

Berdasarkan tabel 2 diketahui bahwa ketepatan pemilihan obat terhadap pasien yaitu sebesar 86\%, ketepatan jumlah pemberian sebesar 100\%, dan ketepatan dosis dan frekuensi pemberian sebesar 83\%. Dari hasil penelitian menunjukkan bahwa masih terdapat pemilihan obat yang tidak tepat sebesar $14 \%$ yaitu pemberian obat yang tidak memiliki efek terapi berdasarkan riwayat penyakit pasien atau keluhan pasien. Menurut (Depkes RI, 2011) menyatakan bahwa obat yang dipilih harus memiliki efek terapi sesuai dengan penyakit dan memiliki resiko efek samping yang rendah atau efek samping obat tidak membahayakan bagi pasien jika dikonsumsi. Selain itu menurut (Soleha et al., 2018) menyatakan bahwa penggunaan
OAINS yang tidak tepat dapat menimbulkan efek samping misalnya lesi gastrointestinal.

Dalam penelitian ini juga terdapat ketidaktepatan dosis dan frekuensi pemberian obat sebesar $17 \%$, dengan kasus pemberian ibuprofen dengan dosis rendah dengan frekuensi 2 kali sehari untuk pengobatan osteoarthritis. Menurut rekomendasi Indonesian Rheumatology Association (IRA, 2014) tentang penggunaan obat anti inflamasi non steroid menyebutkan bahwa dosis penggunaan ibuprofen terbagi dalam rentang dosis rendah yaitu $400 \mathrm{mg}$ setiap 8 jam, dosis menengah $600 \mathrm{mg}$ setiap 6 8 jam, dan dosis tinggi 800 mg setiap 6 jam dalam sehari. Pemberian obat dengan dosis rendah tidak menjamin tercapainya efek terapi dari obat bahkan dapat merugikan pasien dari aspek pembiayan. Dalam penelitian juga terdapat ketidakrasionalan penggunaan OAINS seperti pada penelitian yang dilakukan oleh (Laelatul Hanifah \& EM, 2019) di Instalasi Rawat Jalan RS Dr. Soeradji Tirtonegoro Klaten 2018 menemukan bahwa terdapat pemberian ibuprofen pada pasien osteoartritis yang tidak tepat pasien sebanyak 7 pasien. Dalam kasus penelitiannya ditemukan bahwa ibuprofen dikontraindikasikan terhadap pasien dispepsia dan usia $\geq 75$ namun tetap diberikan, hal ini dapat meningkatkan resiko efek samping karena pemberian OAINS secara oral pada usia manula dapat 
meningkatkan penurunan fungsi ginjal. Berdasarkan uraian tersebut dapat dikatakan bahwa penggunaan OAINS di Puskesmas Poli-Polia Kabupaten Kolaka Timur tidak sepenuhnya rasional. Dari ketiga aspek dalam penelitian ini yaitu ketepatan pemilihan obat, ketapatan jumlah, dan ketepatan dosis dan frekuensi pemberian dapat memberikan gambaran ketidak rasionalan dalam penggunaan obat.

Ketidakrasionalan penggunaan obat memiliki dampak negatif tergantung dari jenis ketidakrasionalan penggunaannya, misalnya berdampak pada mutu pengobatan dan pelayanan, biaya pengobatan, terjadinya efek samping atau efek lain yang tidak diharapkan, dampak terhadap mutu ketersediaan obat, bahkan berdampak terhadap psikososial. Oleh karena itu, pemberian informasi terkait dengan penggunaan obat yang tepat sangat berguna bagi pasien untuk memperoleh pengobatan secara rasional agar tidak terjadi efek samping yang merugikan dan perlu didukung dengan kerjasama yang baik antar tenaga kesehatan, pengetahuan yang mumpuni serta dengan penggunaan pedoman pengobatan yang bisa menjadi petunjuk terapi yang didasarkan pada berbagai penelitian (Soleha et al., 2018; Kemenkes RI, 2011). Adapaun keterbatasan pada penelitian ini yaitu hanya terdapat tiga parameter ketepatan yang dapat diukur untuk mengevaluasi rasionalitas penggunaan OAINS karena terbatasnya informasi yang diperoleh sehingga berpengaruh terhadap parameter ketepatan yang dievaluasi oleh peneliti.

\section{KESIMPULAN}

Rasionalitas penggunaan Obat Anti Inflamasi Non Steroid (OAINS) di Puskesmas Poli-Polia Kabupaten Kolaka Timur dilihat dari aspek tepat pemilihan obat yaitu sebesar $86 \%$, tepat dosis dan frekuensi pemberian sebesar $83 \%$, dan tepat jumlah obat mencapai 100\%. Namun jika dilihat secara keseluran dari aspek tersebut menggambarkan bahwa penggunaan OAINS di Puskesmas tersebut belum sepenuhnya rasional.

\section{UCAPAN TERIMA KASIH}

Terima kasih kami sampaikan kepada Program Studi Farmasi Fakultas Sains dan Teknologi Universitas Mandala Waluya dan Kepala Puskesmas Poli-Polia Kabupaten Kolaka Timur yang telah memberi izin dan membantu dalam penelitian ini.

\section{DAFTAR PUSTAKA}

Andarmoyo, S. (2013). Konsep \& proses keperawatan nyeri. Yogyakarta: Ar-Ruzz Media.

Bahrudin, M. (2018). Patofisiologi Nyeri (Pain). Saintika Medika: Jurnal Ilmu Kesehatan Dan Kedokteran Keluarga, 13(1), 7-13.

Barus, J. (2015). Penatalaksanaan Farmakologis Nyeri pada Lanjut Usia. Cermin Dunia Kedokteran, 
42(3), 167-171.

Depkes RI. (2011). Kebijakan Obat Nasional. Jakarta: Departemen Kesehatan Republik Indonesia.

Ghlichloo, I., \& Gerriets, V. (2021). Nonsteroidal Anti-inflammatory Drugs (NSAIDs). Treasure Island (FL).

Ihsan, S., Sabarudin, S., Leorita, M., Syukriadi, A. S. Z., \& Ibrahim, M. H. (2017). Evaluasi Rasionalitas Penggunaan Obat Ditinjau dari Indikator Peresepan Menurut World Health Organization (WHO) di Seluruh Puskesmas Kota Kendari Tahun 2016. Medula, 5(1), 402-409.

IRA. (2014). Penggunaan Obat Anti Inflamasi Non Steroid.

Kemenkes RI. (2011). Modul Penggunaan Obat Rasional. Jakarta: Kementerian Kesehatan Republik Indonesia.

Laelatul Hanifah, I., \& EM, S. (2019). Rasionalitas Penggunaan Obat Osteoartritis Pada Pasien Osteoartritis Di Instalasi Rawat Jalan Rsup Dr. Soeradji Tirtonegoro Klaten Tahun 2018. Universitas Muhammadiyah Surakarta.

Meara, A. S., \& Simon, L. S. (2013). Advice from Professional Societies: Appropriate Use of NSAIDs. Pain Medicine, 14(suppl_1), S3-S10. https://doi.org/10.1111/pme.1228
2

Schug, S. A., \& Goddard, C. (2014). Recent advances in the pharmacological management of acute and chronic pain. Annals of Palliative Medicine, 3(4), 263275.

Soleha, M., Isnawati, A., Fitri, N., Adelina, R., Soblia, H. T., \& Winarsih, W. (2018). Profil Penggunaan Obat Antiinflamasi Nonstreoid di Indonesia. Jurnal Kefarmasian Indonesia, 8(2), 109-117.

Sostres, C., \& Lanas, Á. (2016). Appropriate prescription, adherence and safety of nonsteroidal anti-inflammatory drugs. Medicina Clínica (English Edition), 146(6), 267-272.

Wahyuni, H., Diana, V. E., \& Suprianto, S. (2019). Rasionalitas Penggunaan dan Kelengkapan Resep Non Steroid Anti Inflamasi Drugs (NSAID) Pada Tiga Puskesmas di Kabupaten Gayo Lues. Jurnal Dunia Farmasi, 3(2), 69-78. Waranugraha, Y., Suryana, B. P. P., \& Pratomo, B. (2013). Hubungan pola penggunaan OAINS dengan gejala klinis gastropati pada pasien reumatik. Jurnal Kedokteran Brawijaya, 26(2), 107-112.

WHO. (2021). Promoting Rational Use of Medicines. 